\title{
Dinamica în limbă
}

\author{
Valentin Dragoș Biro* \\ Scoala Doctorală de Studii Filologice, Universitatea „Alexandru Ioan Cuza”, Bd. Carol I 11, 700506 Iași, România \\ Colegiul Național Pedagogic „Spiru Haret”, Bd. Spiru Haret 6, 120260 Buzău, România
}

\begin{tabular}{ll}
\hline Despre articol & Rezumat \\
Istoric: & Limba este supusă unui proces de dublă definire: prin atributul sistemului de \\
Primit 7 aprilie 2019 & realitate statică, datorată inerției la schimbare, și prin caracterul de permanentă \\
Acceptat 16 aprilie 2019 & producere de acte de limbaj, prin vorbire. Sub presiunea nevoilor concrete de \\
Publicat 7 mai 2019 & comunicare, o limbă se află într-o continuă dinamică ce asigură progresul sau \\
& regresul limbii, ambele aspecte, alături de modificările neutre, reprezentînd, în \\
Cuvinte-cheie: & fapt, evoluția limbii. Articolul vine astfel cu o necesară delimitare conceptuală \\
evoluție & între evoluția și progresul limbii, pe de o parte, dar și între cauzele ce determină \\
darwinism & evoluția și evoluția în sine, ca proces. \\
limbă & Lingvistica a cunoscut abordări radical diferite asupra obiectului său de stu- \\
diacronie & diu, limbajul natural uman: perspectivele asupra limbii diferă de la rețeaua de \\
lingvistică & relații care fac elementele ce compun o limbă sau alta să capete calitatea de sis- \\
& teme, la produs al libertății și voinței umane, căci limba nu poate fi separată de \\
& libertatea vorbitorilor, sau la atenția acordată semnificațiilor, acestea find întot- \\
& deauna construite social, pe baza interacțiunilor dintre membrii unei comuni- \\
& tăți. Într-o atare diversitate a punctelor de vedere exprimate în care divergența \\
domină convergența, articolul își propune în subsidiar să fixeze din perspectivă \\
diacronică definirea lingvisticii ca însemnînd, în principal, istoria evoluțiilor pe
\end{tabular}

\section{Introducere}

\subsection{Limba - obiect de studiu}

Lingvistica este percepută în sens tradițional ca reprezentînd exclusiv studiul științific al limbajului natural uman. Încercînd să se definească pe sine ca fiind o știință autonomă și din dorința de a respecta cerințele considerate legitime pentru existenţa unei științe autonome (să ị̂si găsească, să își individualizeze și să își definească obiectul de studiu; în cazul în care obiectul de investigație intră în sfera de preocupări ale unei alte științe, să identifice și să izoleze aspectele specifice), lingvistica a cunoscut abordări diferite asupra obiectului său de studiu. General acceptată este însă perspectiva conform căreia lingvistica este o știință din sfera științelor socio-umane prin faptul că „se definește prin raportare la acele atribute esenţiale ale ființei umane: facultatea de a cunoaște, capacitatea de a exprima această cunoaștere și deprinderea de a o transmite semenilor” (Milică \& Moisuc, în Notă asupra ediției la Irimia, 2011).

Astfel, încă din Antichitate pînă în secolul trecut, limbajul a fost considerat instrument al gîndirii, al rațiunii (cu care a și fost identificat), mijloc de cunoaștere a unei realităţi percepută ca fiind unică, statică și obiectivă și reflectată în limbaj prin intermediul gîndirii. Apoi, limba a fost percepută prin calitatea sa de instrument de comunicare colectivă, interumană, deci un fapt social sau chiar o instituție socială, un bun supra-individual și independent de intruziunea subiectivă a membrilor unei comunităţi, percepuți independent. Acestei percepții formaliste i se adaugă ulterior și cea structuralistă, ce încearcă să extragă din limbă mai ales rețeaua de relații

\footnotetext{
*Adresă de corespondență: valibiro@yahoo.com.
} 
care fac elementele ce compun o limbă sau alta să capete calitatea de sisteme, transformînd astfel, într-o anumită măsură, o caracteristică definitorie în una exclusivă.

De amintit aici sînt și concepția comportamentalistă (limbajul natural uman și limbile în care se concretizează reprezintă doar un mod de a fi, o conduită, cel mai tipic comportament al ființei umane), concepțiia naturalistă (biologică, organicistă, limbajul fiind văzut ca un organism viu, independent în totalitate și de individ și de societate, supus acelorași reguli fatale ale naturii: maturizare, perfecționare, regres, dispariție) și concepția psihologistă (limba nu mai este privită ca un fenomen determinat cauzal nici de gîndire, nici de legile naturale, ci ca un produs independent $^{1}$ al psihicului uman; limba nu mai este un produs al necesităţii, o impunere ce derivă din calitatea de ființă socială a omului, ci un produs al libertăţii și voinței umane, în sensul în care, dacă limba abstractă depinde de normă, limba reală, concretă, nu poate fi separată de libertatea vorbitorilor).

Frecvent vehiculată este și concepția sociologică: orice limbaj este un sistem de codare, iar pentru a putea exista comunicare și interacțiuni sociale, este nevoie ca actanții procesului de comunicare să aibă același sistem de coduri sau, altfel spus, să opereze cu aceleaşi tipuri de semnificaţii; acest lucru este posibil doar pe baza unor relații sociale relativ stabile la nivelul comunității în care este prezent respectivul limbaj; această condiție este universală și se aplică în cazul oricărui tip de limbaj, semnificațiile fiind întotdeauna construite social; semnificațiile se impun, se păstrează, se schimbă în timp doar pe baza interacțiunilor dintre membrii unei comunități.

Din diversitatea punctelor de vedere exprimate, rețin aici o definiție a lingvisticii din perspectivă evolutivă: „La nivel general, dacă s-a înțeles că întreaga biologie nu este decît istoria diferențierilor pe care organismele de un același tip le-au suferit adaptîndu-se diverselor medii, se poate afirma că lingvistica nu este decît istoria evoluțiilor, diverse în funcție de neamuri şi de locuri, prin care a trecut tipul primitiv" (Darmesteter, 2015).

\subsection{Limba-perspective}

Înrudite și nicidecum separabile sînt perspectivele din care se poate privi orice știință, perspective aflate la rîndul lor în logică și demonstrabilă interdependență: (a) perspectiva sincronică - cea care are a descrie orice aspect al unei științe, materie, obiect de studiu prin ceea ce reprezintă în sine, static; (b) perspectiva diacronică - cea care are a prezenta orice aspect al unei științe, materie, obiect de studiu prin raportare la evoluția sa în timp, dinamic.

Descrierea (perspectiva sincronică) și istoria (perspectiva diacronică) nu se exclud din punctul de vedere al obiectului de studiu, nu sînt antitetice sau contradictorii, ci complementare.

Raportat la domeniul lingvisticii (ca știință), au existat numeroase luări de poziție referitoare la nevoia transformării în complementaritate a dihotomiei sincronic - diacronic; amintesc aici doar cîteva, cu rol exemplificativ, fără a exista nici pe departe pretenția exhaustivității specifice unui metastudiu:

„La cunoaștere, așadar, se ajunge abia după înțelegerea faptului că descrierea acurată a elementului și a stării folosesc numai dacă, după ce au fost privite o clipă separat, sînt concepute în devenirea lor unitară. Întrucît nici structura și nici funcția nu există ca atare în afara întregului pe care dimpreună și deopotrivă îl constituie și servesc, spre a pricepe cum se cuvine este nevoie ca scrutarea stării să fie urmată de examinarea proceselor entității - în contextul larg al existenței acesteia. $\mathrm{O}$ atare cuprindere se dobîndește prin examinarea materialului care temeinicește întreaga cercetare, alternînd repetat analiza microscopică cu sinteza telescopică, în care

\footnotetext{
${ }^{1}$ Wihelm von Humboldt a definit limbajul ca fiind o realitate liberă și creativă, nicidecum un produs dat și preluat ca atare (în Über die Verschiedenheit des menschlichen Sprachbaues und ibren Einfluss auf die geistige Entwicklung des Menschensgeschlechts [Cu privire la diversitatea limbajului uman și influența acestuia asupra dezvoltării spirituale a rasei umane]).
} 
axa perspectivelor (sincronică, a stării, și diacronică, a procesului) se întrețese cu cea a metodelor (inductivă, a certitudinilor particular-concrete, și deductivă, a sugestiilor universal-abstracte)" (Gafton \& Gafton, 2016, p. 9);

„Relația dintre aspectul sincronic și cel diacronic al limbii este dialectică, caracter neignorat, de fapt, de Saussure, cum ar lăsa unii lingviști postsaussurieni să se înțeleagă” (Irimia, 1978, p. 255);

„În ultimul timp s-a semnalat adesea nevoia de a atenua rigiditatea dihotomiilor saussuriene. S-a spus, pe bună dreptate, că trebuie umplută prăpastia săpată de Saussure între langue şi parole. Și, în ceea ce privește limba, s-a insistat asupra necesităţii de a umple prăpastia dintre sincronie și diacronie, ceea ce este în multe privințe necesar [...]. Să nu uităm că antinomiile stabilite de Saussure au fost explicit respinse de o întreagă serie de studii” (Coșeriu, 1997, p. 14). Exemplul adus este cel al lui H. Schuchardt care, într-o recenzie la Cursul de Lingvistică Generală (Hugo Schuchard-Brevier, Halle, 1928, p. 330), scria, cu privire la separația dintre lingvistica sincronică și cea diacronică: „Aceasta îmi apare ca și cum am disocia învățătura despre coordonate într-una despre ordonate și alta despre abscise. În limbă, ca, de altfel, în general, repaosul și mișcarea (aceasta considerată în sensul cel mai larg) nu formează o opoziție [...]”.

„[...] Încă din 1870, vorbind despre sistemul limbii, Baudouin de Courtenay găsește în el nu numai corelațiile dintre elementele sincronice, ci și faptul că acestea reprezintă rezultatul evoluției anterioare și, în acelaşi timp, baza dezvoltării ulterioare: «Mecanismul limbii și, în general, structura și elementele sale într-un anumit moment reprezintă rezultatul întregii istorii anterioare a ei, a întregii evoluții, și, invers, acest mecanism, într-un anumit moment, condiționează evoluția ulterioară a limbii [...]». Și, în sfîrșit: «Nu există repaus în limbă... în limbă ca și, în genere, în natură, totul trăiește totul se mișcă, totul se transformă. Liniștea, oprirea, stagnarea sînt fenomene aparente, reprezintă un caz particular al mișcării, în condițiile unei modificări minime. Statica limbii este numai un caz particular al dinamicii sau, mai bine zis, al cinematicii ei»." (G. Mihăilă, Raportul dintre sincronie și diacronie, în Graur et al., 1971, p. 359).

Și exemplele pot, evident, continua.

Concluzionînd, dinamica limbii, permanenta devenire a culturii lingvistice vădită în producția continuă de texte, pe de o parte, și variațiile culturale, pe de altă parte, determină o abordare atît din perspectivă sincronică, cît și diacronică.

\section{Limba - sistem și structură}

Abordarea alternativ sincronică și diacronică este impusă de granița fină ${ }^{2}$ ce separă noțiunile de sistem și structură în ceea ce privește organizarea internă a limbii. Sistemul este ansamblul semnelor lingvistice și al relațiilor dintre ele. Diferențierea și opoziția definesc semnul lingvistic: fiecare semn există pentru că face parte din sistem și are o identitate pentru că se opune altora. Structura este configurată de ansamblul relațiilor pe care le dezvoltă sau ipotetic le pot dezvolta semnele lingvistice. Practic, structura reprezintă modalitatea de existență și funcționare a sistemului. Ambele se definesc însă prin raportare la semnul lingvistic, care, în interiorul sistemului, își definește identitatea prin poziția pe care o ocupă în diferitele serii de opoziții paradigmatice: „Structura determină și relevă valoarea semnelor lingvistice, care se concretizează în tipul de unități funcționale și semnificative, în care este organizat un enunţ. Cum distincția sistem - structură este posibilă numai în sfera interpretării, deși este reală, nici identitatea şi valoarea nu pot fi diferențiate în realitatea obiectivă a limbii” (Irimia, 1978).

\footnotetext{
${ }^{2}$ „Raportul dintre sistemul și structura limbii este indisolubil, pînă aproape de confundarea lor. Nu de puține ori, de altfel, cei doi termeni au fost și sînt interpretați în sinonimie (la Humboldt) sau unul în locul celuilalt (mai frecvent, în ultima vreme, «structură » în locul lui «sistem»: la Piaget și la alții)" (Irimia, 1978).
} 
Semnul lingvistic se află orientat în acelaşi timp către lumea obiectelor ${ }^{3}$ și către sistemul semiotic al limbii din care face parte ${ }^{4}$. Utilizatorul percepe ambele orientări în propria conștiință în procesul de emitere și receptare, adică de utilizare continuă și nemijlocită a limbii. Relația dintre semnificat și semnificant presupune în realizarea ei concretă intersectarea axei relațiilor sintagmatice cu cea a relaţiilor paradigmatice. Intersectarea celor două axe reflectă raporturile strînse dintre sistem și structură, pe de o parte, și între limbă și vorbire în actul lingvistic real, în cadrul căruia se realizează procesul de semnificare, pe de altă parte. În planul paradigmatic, semnele sînt investite cu o valoare virtuală în orientarea procesului de semnificare, în funcție de clasele și categoriile de semne în care se află grupate; în planul sintagmatic, varietatea virtuală este înlocuită de o alegere concretă. Semnificația semnului este astfel o rezultantă a influenței semnelor vecine și a influenței semnelor care ar fi putut sau nu să apară în locul celui prezent.

Am văzut deja că perspectivele asupra limbii diferă în timp, de la rețeaua de relații care fac elementele ce compun o limbă sau alta să capete calitatea de sisteme, la produs al libertății și voinței umane, în sensul în care limba reală, concretă, nu poate fi separată de libertatea vorbitorilor, sau la atenția acordată semnifcațiilor, acestea fiind întotdeauna construite social căci ele se impun, se păstrează, se schimbă doar pe baza interacțiunilor dintre membrii unei comunități. Departe de a se exclude, aceste abordări reprezintă, de fapt, fațete ale aceleiași realități ${ }^{5}$ care este limba și care se vădește prin limbă. Astfel, în plan paradigmatic, limba se definește ca un sistem ce se folosește de o varietate virtuală de semne aflate în relație, pentru ca, în plan sintagmatic, semnele constituite în sistem să capete semnificație concretă prin alegerea liberă, voită, conștientă a vorbitorilor, alegere fundamentată pe interacțiunea anterioară cu membrii unei comunităţi stabile din punct de vedere lingvistic.

Acceptînd existența celor două planuri, devine imposibilă perceperea limbii ca fiind o realitate sieși suficientă ${ }^{6}$, statică și indiferentă față de realitatea extralingvistică, deși au existat abordări în acest sens .

${ }^{3}$ În cadrul raportului limbă - gîndire.

${ }^{4}$ În cadrul raportului limbă - societate.

${ }^{5}$ Știința nu se poate deosebi de obiectul său de studiu, de subiectul cercetării - realitatea conținînd nenumărate fațete, astfel încît diferite științe se ocupă de dezvăluirea realităţii din diferite puncte de vedere. Pe de altă parte, realitatea, pe cît de diversificată în manifestare, are un caracter unitar și, prin urmare, poate fi percepută pe deplin, atît cît este posibil, doar dacă se mizează pe un sincretism al științelor, căci funcționarea optimă a unui organism, atît în fiecare moment al existenței sale considerat separat, cît și în existența sa cursivă și neîntreruptă, nu rezidă din activitatea separată a celulelor care îl compun, ci din coeziunea acestora (apud Gafton \& Gafton, 2016).

${ }^{6} \hat{I}$ istoria lingvisticii, abordările asupra rolului, obiectului, metodelor au evoluat de la apariţia tentației de a-și căuta în sine toate răspunsurile, limba fiind concepută ca separată de realitatea a cărei parte era, dobîndind „complexul autonomiei autarhice”, la „ademenitorul gînd că limba este un sistem de semne, pe de-a întregul guvernat de legi interne” (Gafton \& Gafton, 2016).

${ }^{7}$ Respinse fără putință de tăgadă în comunitatea științifică: „După cum se vede, abordarea din perspectivă sincronică ar putea oferi analize amănunțite, crezînd că a găsit în texte ceea ce de fapt nu se află acolo, și neștiind să afle ceea ce se găsește acolo. Ar interpreta greșit forme, funcții și sensuri și ar pierde tocmai ceea ce conferă importanță acelui text - în cadrul cercetării lingvistice și în general. Imaginea astfel oferită ar corespunde unei scheme deductive sau unui construct mental extrapolat, adică unor proiecții sau conjecturi, dar ar fi lipsită de singurul lucru necesar: indispensabilele temeiuri furnizate de realitatea cercetată, conectată la realitatea supraordonată și în măsură să ofere rezultate științifice valide. După ce perspectiva diacronică stabilește trăsăturile generale și particulare ale întregului context, parcursul procesual ce-a generat textul, rezultatele evolutive ale limbii române, efectele contactelor acesteia cu factorii de influență, particularitățile amorsării și edificării vechiului aspect literar românesc, perspectiva sincronică poate exercita o acțiune eficientă, în cadrul unui proces conjugat și alternativ, al ambelor perspective. Aceasta întrucît nici o entitate privită static și excizată din organismul la care este parte nu poate genera cunoaștere, nici măcar despre sine însăși întrucît, decontextualizată, ea nu se mai poate referi la sine în context, ci la noua ei stare, aparentă” (Gafton \& Gafton, 2016). Sau: „Opoziția se înscrie, de altfel, în prelungirea celei dintîi, dimensiunea diacronică a limbii avîndu-şi punctul de plecare în vorbire. La fel cum limba şi vorbirea nu puteau constitui obiectul aceleiași lingvistici, datorită caracterului eterogen al limbajului uman considerat în ansamblu, dimensiunea sincronică și cea diacronică nu pot fi investigate - în concepția lui Saussure — de o aceeași lingvistică, din cauza caracterului disparat al faptelor de limbă sincronice și diacronice, atît prin legile diferite care le guvernează, prin natura și modul specific al funcționării, cît și prin caracterul specific al metodelor de investigație. [...] Este adevărat că pentru conștiința vorbitorului, limba nu există, în actul viu al comunicării, decît în sincronie cu el [...]. Este adevărat că «cea mai bună modalitate de a cunoaște esența și caracterul unei limbi este analiza sincronică a faptelor concrete» (B. de Courtenay), dar pentru cunoașterea procesului de constituire a unui sistem lingvistic are importanță deosebită interpretarea schimbărilor produse în timp, o dată cu evoluția comunitătiii lingvistice respective. Tocmai caracterul de fenomen social al limbii impune interpretarea atît a realității ei sincronice cît și a celei diacronice, cu atît mai mult 
Astfel, limba este supusă unui proces de dublă definire: pe de o parte, prin atributul sistemului de realitate statică, datorată inerției la schimbare, și, pe de altă parte, prin caracterul de permanentă producere de acte de limbaj, prin vorbire.

Această producție permanentă de acte de limbaj depinde de arbitrarul alegerilor pe care vorbitorul ${ }^{8}$ le face. În Cursul său, Saussure subliniază rolul esențial al arbitrarului în producerea actelor de limbă: la originea distincțiilor pe care semnificanții și semnificații le introduc în vorbire și la originea sensului pe care îl capătă mai apoi se află capacitatea înnăscută a omului de a discrimina și de a asocia în clase, de a face alegeri, și de a utiliza ulterior în mod diferit aceste clase: „Nu trebuie să înțelegem că vorbitorul ar fi complet liber să-şi stabilească termenii şi că, dacă ar avea chef, ar putea să-i întrebuințeze altfel decît a auzit de la alții. O oarecare libertate există, bineînțeles, și ea stă la baza stilurilor individuale. [...] Sîntem obligați să ne folosim de cuvintele pe care le cunosc și ceilalți, cu înțelesurile pe care le-am învățat [...]” (Graur et al., 1971).

Importanța arbitrarului este subliniată de Tullio De Mauro în studiul critic ce precede Cursul de lingvistică generală al lui Saussure: „Din arbitrar decurg alte două caracteristici antitetice ${ }^{9}$ ale limbii. Înainte de toate, mutabilitatea sa în decursul timpului [...]. Se întîmplă astfel ca niște tradiţii lingvistice îndepărtate să înceapă să conveargă, sau ca aceeași tradiție lingvistică să se poată scinda în idiomuri profund divergente. Limbile nu au în fața lor alte limite în afară de acelea, numai și cu adevărat universale (universale, bineînțeles, pentru specia umană), ale structurii aparatului perceptiv și conștient al omului și ale aparatului său fonator și acustic: în interiorul acestora, posibilitățile de a regrupa în semnificanți și în semnificați infinita serie a diferitelor fonii și a diferitelor sensuri sînt nelimitate. În ultimă analiză, arbitrarul amortizează zguduirile provocate de posibilele schimbări ale foniilor și ale semnificaţiilor. [...] Uzajul pe care societatea îl dă limbii este condiția pentru ca limba să fie viabilă. [...] Întocmai ca arbitrarul, legătura socială este factor de stabilitate și, în același timp, de schimbare. Tocmai faptul că ea este socială ferește limba de capriciile indivizilor sau ale grupurilor restrînse ${ }^{10}$. Pe de altă parte, același caracter social expune limba la schimbări, atunci cînd nevoia de distincții deja existente se micșorează sau, dimpotrivă, atunci cînd se ivește nevoia de noi distincții”.

De remarcat că această perspectivă este și ea supusă în timp unei analize critice ce-i nuanțează delimitările; de exemplu, în Benveniste (1966) se consideră că arbitrar poate fi definit doar raportul dintre semnul lingvistic și o realitate extralingvistică.

cu cît stări sincronice pure nu există și, în consecință, însăşi descrierea sistemului dintr-o anumită etapă impune interpretarea unor fenomene rezultate din coexistența unor forme noi cu altele tradiționale” (Irimia, 1978).

${ }^{8}$ Includ aici diferența esențială limb $\breve{a}$ - vorbire, astfel încît prin noțiunea de vorbitor mă refer la un utilizator al unui sistem lingvistic în procesul de producere de noi texte. Asupra acestui aspect, relația vorbitor - arbitrar, voi reveni.

${ }^{9}$ Alături de opozivitate și linearitate.

${ }^{10}$ Față de această abordare, se naște însă întrebarea legitimă legată de modalitatea (sau criteriile) care determină un fapt de limbă sau altul să fie încadrat în această categorie. În principiu, ar fi necesară o comparație cu ceea ce se constituie în cutumă din punct de vedere lingvistic, starea de echilibru către care a tins limba pînă în acel moment, stare acceptată și adoptată, pentru a se constata gradul de viciere. Astfel, s-ar analiza doar o stare de limbă, adică o abordare exclusiv sincronică, perspectivă deja stabilită ca fiind indezirabilă prin caracterul său limitativ. Se justifică însă transformarea binomului limbă - vorbire în trinomul limbă vorbire - normă din accepțiunea lui E. Coșeriu (norma: „sistem de realizări obligatorii, consacrate din punct de vedere social și cultural”; ,ea....corespunde la ceea ce s-a spus și în mod tradițional se spune în comunitatea considerată”; „cuprinde modelele deja realizate istoric”; „corespunde fixării limbii în tipare tradiționale” etc.). Pe de altă parte, chiar și un capriciu reprezintă un fapt de limbă, cu manifestare reală la un moment dat, deci, utilizînd chiar accepțiunea saussuriană, unica realitate lingvistică pentru respectivul individ sau pentru respectivele grupuri restrînse. Pentru vorbitori, incapabili să își poziționeze propriile particularitățile definitorii de utilizare a limbii în procesul istoric al comunicării, aceste capricii reprezintă cultura lingvistică ce îi definește în uzul limbii. 


\section{Dinamica în limbă}

Din punctul de vedere al raportului dintre vorbitor și limbă, însă, semnul lingvistic este aproape în mod absolut nearbitrar. Vorbitorul ${ }^{11}$, în afara unor limite care țin de întrebuințarea stilistică a limbii, nu este liber nici să schimbe raportul dintre un semn lingvistic și realitatea desemnată, nici să modifice după propria voinţă structura semnificatului și a semnificantului. Cîtă vreme libertatea de alegere a vorbitorului este (aproape) deplină pe de o parte, dar (în totalitate) limitată pe de alta, se impune identificarea ansamblului de factori ce determină existența unei limbi într-o anumită formă sau alta, la un anume moment dat (din perspectivă sincronică) sau în momente diferite de manifestare (din perspectivă diacronică).

Istoria unei limbi (istoria constituirii sale ca sistem semiotic distinct și devenirea ei pînă la stadiul sincronic cunoscut subiectului vorbitor) cunoaște două mari etape: (a) constituirea sistemului propriu, prin destrămarea și apoi dezvoltarea specifică a sistemului limbii - bază ; (b) evoluția sistemului prin permanente treceri de la un echilibru la altul, în aspirația spre atingerea unui grad maxim de stabilitate și regularitate. Procesul se desfășoară în interiorul raportului limbă - vorbire, caracterizat de o permanentă stare de tensiune între imperativul adoptării la nevoile comunicării, mereu schimbătoare (în perioada de formare, în mod radical schimbătoare), și exigențele impuse de funcționalitatea limbii pentru întreaga comunitate. Norma este mai ales ignorată sau uneori de-a dreptul respinsă, iar generalizarea abandonării normei duce, în perioada de formare, la distrugerea echilibrului vechiului sistem și construirea unui alt echilibru.

Factorii care condiționează constituirea noului sistem lingvistic și, după aceea, procesul neîntrerupt al diacroniei sale, adică al existenței sale reale, sînt multipli. Unii sînt extra-lingvistici, alții sînt de natură lingvistică ${ }^{12}$, unii derivă din alții sau intră in conflict cu ei, dar toți acționează, mai ales împreună, în strînsă legătură cu funcția de comunicare a limbii, care impune în permanență noi exigențe. Între cele două serii de cauze, externe și interne, se desfășoară de fapt relații complexe, de la implicație pînă la poziție, a căror natură se schimbă în funcție de etapa istorică în care se află limba. În etapa constituirii noului sistem, cauzele externe au un rol activ, deosebit de accentuat. Ulterior, sistemul își cîștigă o relativă autonomie față de ele, iar rolul activ revine cauzelor interne care acționează în sensul regularizării sistemului și stabilizării echilibrului său. Dar, dincolo de această schimbare de pondere, îmbinarea cauzelor interne cu cele externe este permanentă, derivînd din însăşi funcția de comunicare a limbii, din caracterul ei de fenomen social, din întrebuințările ei de către subiectul vorbitor care își situează mereu actul lingvistic între limbă și vorbire ${ }^{13}$.

Factorii extra-lingvistici (originea și istoria unui neam, nivelul de dezvoltare a civilizaţiei spirituale, caracterul etnic, dezvoltarea economică, socială, culturală, politică a comunității sociallingvistice) reprezintă cadrul general în care se constituie o limbă. Fără să intervină direct în modificarea limbii, aceștia orientează acțiunea factorilor lingvistici ${ }^{14}$.

Factorii lingvistici externi (contactul între limbi, bilingvismul, poziția subiectului vorbitor sau a unui grup social față de limbă) vin în prelungirea factorilor extra-lingvistici, care îi condițio-

\footnotetext{
${ }^{11}$ Situat, prin normă, între limbă (totalitatea posibilităților, libertăților oferite) și vorbire (totalitatea posibilităților transformate în fapte, deci ansamblul de libertăți luate).

${ }^{12}$ La Graur et al. (1971), cauze interne și cauze externe.

${ }^{13}$ „Din urmărirea factorilor care condiționează, stimulează sau chiar cauzează schimbările în limbă, se impune o concluzie asupra căreia au atras atenția Saussure, S. Pușcariu, A. Martinet, Al. Graur ș.a.: nu există o anumită cauză, internă sau externă, care, singură și cu obligativitate, să provoace un anumit fenomen. Schimbările care se produc în structura sistemului lingvistic, și prin acesta, în structura sistemului-favorizate în mod esențial deopotrivă de arbitrarul relației interne, dintre semnificant și semnificat, și al raportului dintre limbă și planul ontologic, și de tendința spre motivare a lui-derivă dintr-o cauzalitate complexă, în care un factor poate avea la un moment dat un rol mai important dar acțiunea sa se corelează cu acțiunea altor factori. Evoluția limbii este o rezultantă a mișcării interne a sistemului (absolutizată de unele direcții în fonologia diacronică), nevoilor obiective ale comunicării și poziției, subiective sau obiective, a subiectului vorbitor” (Irimia, 1978).

${ }^{14}$ În aceeași direcție, E. Coșeriu consideră că aceștia „funcționează, în materie de schimbare, ca selectori ai inovațiilor: ei
} 
nează în acțiunea lor consecutivă sau simultană: „Rolul cel mai important în producerea unor modificări îl au inovațiile izvorîte din forța creatoare a subiectului vorbitor, caracteristică în primul rînd scriitorilor şi creatorilor populari. Rolul scriitorilor devine cu deosebire activ în anumite perioade ale istoriei unei limbi, esențiale pentru regularizarea sistemului, prin constituirea unei norme mai fidele spiritului profund al sistemului limbii. Cîtă vreme, însă, inovaţiile rămîn individuale, ele de fapt nu interesează sistemul limbii, indiferent ce origine ar avea, nu ajung să-l influențeze în nici un fel, ci rămîn în sfera vorbirii. Pentru a deveni fapte de limbă, inovațiile au de înfruntat, în răspîndirea lor, inerția, atitudinea conservatoare a unor categorii sociale, de vîrstă. Răspîndirea lor pe orizontală, pe teritorii mai mult sau mai puțin extinse, este condiționată de răspîndirea lor pe verticală, în sfera diferitelor categorii de vîrstă, de sex, de cultură. Prin această exigență a socializării, inovația se impune, de fapt, în diacronia limbii ca inovație colectivă” (Irimia, 1978).

Factorii lingvistici interni sînt, de fapt, niște principii foarte generale de funcționare a limbii în sincronie care se impun ca legi, mai mult sau mai puțin imperative în diacronie: efortul minim, economia limbii, randamentul funcțional, integrarea în sistem în plan paradigmatic, interacțiunea semnelor și unităților lingvistice în sistem ${ }^{15}$.

Între factorii lingvistici externi şi cei interni, raporturile sînt de interdependență. Factorii externi acționează asupra sistemului, întrucît sînt cauzaţi de factori extra-lingvistici, dar și pentru că sistemul însuși reclamă o serie de modificări în legătură cu reorganizarea echilibrului său interior. Echilibru interior este, însă, clătinat de acțiuni ale (sau și ale) factorilor externi. Această dinamică face ca acțiunea factorilor interni să se împletească în permanență cu cea a factorilor externi. Sistemul limbii este astfel reprezentat de ansamblul semnelor lingvistice și al relațiilor dintre ele. Diferențierea și opoziţia definesc semnul lingvistic: fiecare semn există pentru că face parte din sistem și are o identitate pentru că se opune altora. Structura este configurată de ansamblul relațiilor pe care le dezvoltă sau ipotetic le pot dezvolta semnele lingvistice. Practic, structura reprezintă modalitatea de existență și funcționare a sistemului. Ambele se definesc însă prin raportare la semnul lingvistic, care, în interiorul sistemului, își definește identitatea prin poziţia pe care o ocupă în diferitele serii de opoziții paradigmatice.

În planul paradigmatic, semnele sînt investite cu o valoare virtuală în orientarea procesului de semnificare, în funcție de clasele și categoriile de semne în care se află grupate; în planul sintagmatic, varietatea virtuală este înlocuită de o alegere concretă. Astfel, în plan paradigmatic, limba se definește ca un sistem ce se folosește de o varietate virtuală de semne aflate în relație, pentru ca, în plan sintagmatic, semnele

sînt condiții și limite ale libertății lingvistice în acțiunea acesteia de facere și refacere a limbii. Dintre nenumăratele inovații care se constată în vorbire, numai unele se adoptă și se răspîndesc, pentru că numai unele corespund posibilităților și necesităților sistemului funcțional sau găsesc condiții favorabile în starea științei lingvistice individuale. O schimbare lingvistică începe și se dezvoltă, totdeauna, sub formă de deplasare a unei norme. Dar, pentru ca norma să se poată deplasa, este absolut necesar fie ca acest lucru să fie oportun și necesar din punct de vedere funcțional, fie ca norma să nu fie cunoscută, fie ca necunoașterea acesteia să nu afecteze funcționalitatea limbii (înțelegerea între vorbitori). Fiind o știință tradițională, limba se modifică mai ales în punctele sale slabe, adică acolo unde sistemul nu corespunde în mod eficient necesităților expresive și comunicative ale vorbitorilor; modificările necesare își găsesc însă limita în siguranţa tradiției” (apud Irimia, 1978, p. 124).

${ }^{15}$ „Antinomia dintre tendința de asimilare a fonemelor intrate în relații sintagmatice și tendința conservatoare a relațiilor paradigmatice se echilibrează prin transformarea trăsăturii distinctive în unitatea a schimbării; menţinerea (sau realizarea) diferenței maxime a fonemelor; organizarea sistemului (limba tinde spre un caracter mereu sistematic). În antinomia dintre tendința spre asimilare a fonemelor vecine în plan sintagmatic și tendința spre conservare, proprie planului paradigmatic, acțiunea legilor fonetice este contracarată de acțiunea analogiei. Prin atracția sistemului apoi, se completează unele serii de opoziții, umplîndu-se «căsuțele goale». De aici nu trebuie să se înțeleagă nici că sistemul își caută, printr-o forță interioară proprie, mijloace pentru «umplerea» tuturor «căsuțelor goale», nici că sistemul ar putea ajunge la un moment dat la un stadiu de perfecțiune, dincolo de care evoluția ar înceta, și nici că limbile ar introduce prin împrumut fenomene care îi lipsesc. Se împrumută numai semne lingvistice iar acestea se adaptează sistemului fonologic și morfologic al limbii împrumutătoare (în care proces un rol important revine din nou analogiei). Principiul economiei limbii poate determina menținerea «neadaptată »a unor semne, eventual tocmai în sensul realizării unui nou echilibru, deschizînd drum dezvoltării sau extinderii unei anumite opoziții fonologice” (Irimia, 1978). 
constituite în sistem să capete semnificaţie concretă prin alegerea liberă, voită, conștientă a vorbitorilor, alegere fundamentată pe interacțiunea anterioară cu membrii unei comunități stabile din punct de vedere lingvistic.

Arbitrarul are un rol esențial în producerea actelor de limbă: la originea distincțiilor pe care semnificanții și semnificații le introduc în vorbire și la originea sensului pe care îl capătă mai apoi se află capacitatea înnăscută a omului de a discrimina și de a asocia în clase, de a face alegeri, și de a utiliza ulterior în mod diferit aceste clase. Din punctul de vedere al raportului dintre vorbitor și limbă, însă, semnul lingvistic este aproape în mod absolut nearbitrar: „Vorbitorul, în afara unor limite care țin de întrebuințarea stilistică a limbii, nu este liber nici să schimbe raportul dintre un semn lingvistic și realitatea desemnată, nici să modifice după propria voință structura semnificatului și a semnificantului: Se înțelege prin $\operatorname{arbitrar}^{16}$ faptul că în natura obiectului nu există elemente care să oblige la folosirea unui complex sonor și nu a altuia ${ }^{17}[\ldots]$ De fapt, graiul sa născut atunci cînd oamenii în devenire au căzut de acord, fără convenție prealabilă, asupra unei legături permanente între un complex sonor şi un sens, şi acest lucru nu s-a putut produce decît acolo unde sunetele, prin însăși constituția lor, sugerau ideea care trebuia exprimată. După ce în numeroase împrejurări acelaşi grup de sunete a produs aceeași reacție, omul a devenit conștient de faptul că, scoțînd anumite sunete, o poate provoca la cei îl ascultă. Atunci a început să vorbească cu intenție și curînd a simțit nevoia de cuvinte noi, care să denumească noțiuni inexistente mai înainte. Deci a ajuns să creeze cuvinte cu intenția de a le crea” (Graur et al., 1971).

Se admite ${ }^{18}$ că, în general, cauzele schimbărilor în limbă nu se pot uşor identifica și nu întotdeauna este clar motivul preeminenței acțiunii uneia în defavoarea altora, cu urmări care pot însemna optimizarea unui aspect al limbii și, concomitent, complicarea altuia, deși ultimii ani au consemnat apariţia unor lucrări capitale asupra acestor aspecte, în fonologie, morfologic, sintaxă, semantică diacronică. Resortul principal în mișcarea limbii îl constituie permanenta tensiune (și, de aici, echilibrul) dintre nevoia de transmitere clară, exactă și nuanțată a conținutului, pe de o parte, și tendința de simplificare a formei, pe de altă parte, realitate de care vorbitorul obişnuit (sau o întreagă generație de vorbitori) nu este conştient(ă) și pe care nu o creează pentru ea însăși. Alături de acest resort central acţionează, imprimînd ritmuri diferite de evoluție, dar neafectînd esențial continuitatea (cîtă vreme schimbările sînt graduale în comunitatea de vorbitori), factori sociali și istorici, contactul dintre limbi, factori geografici, culturali, tradiția scrisului, sistemul lingvistic însuși. Astfel încît: „În limbă nu domnește spontaneitatea, căci astfel s-ar produce haos, și nu domnește nici finalitatea ${ }^{19}$, căci astfel toate modificările s-ar face în sensul progresului. Sub presiunea nevoilor de comunicare, din ce în ce mai complexe, o limbă se transformă necontenit, pe baza legilor ei interne obiective și a intervenției conștiente care ține seama de aceste legi” (Wald, 2017).

Rezultă din cele prezentate anterior că limba, aflată sub o permanentă presiune din interiorul sistemului ${ }^{20}$ și din exteriorul său ${ }^{21}$, supusă alegerilor individuale și variațiilor contextului social și istoric, se află într-o permanentă dinamică, schimbare, încă de la începuturile sale.

În afara unor situații în care contextul impune respectarea unor convenții terminologice, schimbarea se manifestă, ca necesitate expresivă, în mod spontan și imediat și nu ca o intenție deliberată

\footnotetext{
${ }^{16} \mathrm{~A}$ nu se confunda cu noțiunea 'nemotivat'.

${ }^{17}$ Ceea ce se poate ușor demonstra și logic și faptic prin argumentul că fiecare limbă folosește alt termen pentru a exprima una și aceeași idee (ceea ce în limba română se numește nămol, în germană este schlamm, în engleză mud, în maghiară iszap sau sár, în spaniolă barro, în turcă kerpiç, în rusă zpязs (gryaz), în italiană fango etc.) sau că în într-o limbă același obiect poate avea mai multe nume (limba română cunoaște utilizarea simultană a următoarelor cuvinte: noroi, glod, tină, nămol, mîl, fiecare cu nuanțele sale de sens).

${ }^{18}$ Wald (2017, p. 287-311).

${ }^{19}$ Cum parțial considera, de exemplu, E. Coșeriu.

${ }^{20}$ Factorii lingvistici interni.

${ }^{21}$ Factorii lingvistici externi și factorii extra-lingvistici.
} 
de modificare a limbii percepută ca modalitate de comunicare interindividuală (am preferat termenul de „interindividual” celui de „colectiv” pentru a sublinia faptul că această colectivitate, lingvistică în esență, dar nu exclusiv, reprezintă suma participărilor individuale la actul de comunicare). Astfel, se observă existența simultană a unor elemente inovatoare și a unor elemente lingvistice vechi, neînlocuite încă. Mai mult decît atît, alegerile se manifestă individual, dar ele sînt influențate de tradiția lingvistică ce se regăsește în cultura lingvistică a fiecărui individ și de contextul socio-istoric: o alegere teoretic individuală pe axa sintagmatică este, în fapt, în egală măsură libertate și tradiție, cultură și cultură lingvistică, subiectivitate și obiectivitate, denotație și conotație.

\section{Evoluţie sau progres?}

Este evident caracterul profund dinamic al limbii, dinamică existentă în limba reală, vorbită, uneori sedimentată în texte, manifestat fără întrerupere de la începuturile limbajului și pînă în prezent. Despre caracterul static al limbii se poate vorbi doar dacă se analizează decupaje din limbă, aspecte care se manifestă la un moment dat, deci specifice unei abordări exclusiv sincronice, sau în relație cu capacitatea, limitată pînă la a deveni nulă, a vorbitorilor de a conștientiza rolul individual, activ totuși, pe care îl au în existența limbii. Dar, chiar și așa, decupajele respective reprezintă fotografia unui moment real în conștiința vorbitorilor în contextul de manifestare practică a abilităţii de comunicare. Despre caracterul static se poate vorbi astfel doar în relație cu limba abstractă.

Dinamica limbii însemnă, în principiu, schimbare. Limba care nu se schimbă este limba abstractă, care nu se află sub influența factorilor externi menționați anterior; limba reală, în existența ei concretă, se află într-un permanent proces de schimbare, căci nu poate fi izolată de influența nici a factorilor externi, nici interni, adică tot ceea ce se constituie în istoricitatea și libertatea de expresie a vorbitorilor ${ }^{22}$ dintr-o comunitate lingvistică. Faptele sociale nu sînt exterioare indivizilor, ci sînt interindividuale, adică sînt individuale doar în măsura în care sînt împreună cu alții. Limba mai presus de toate celelalte fapte sociale nu îi este străină (cu sensul de exterioară) individului, nu îi este impusă, ci se realizează prin participare cu ajutorul individului, care o recunoaște ca fiind a sa în egală măsură în care el recunoaște că este și a altora.

Prin urmare, schimbarea nu este nici a individului vorbitor, dar nici nu îi este străină. Schimbarea se realizează cu individul, fără însă ca acesta să iși propună să schimbe ceva. Limba înseamnă pentru un individ sistemul utilizat astfel încît să vorbească la fel ca ceilalți, ca parte a unei comunități lingvistice, act de vorbire ce utilizează modalități și reproduce modele anterioare pe care le-a găsit în comunitatea lingvistică din care face parte.

Mecanismele dinamicii implică așadar actul de vorbire, de utilizare reală a limbii; limba se schimbă pentru că este o este o activitate creatoare, în care vorbitorul își formulează mesajul cu ajutorul unor tehnici anterioare depozitate în știința sa lingvistică, astfel încît el utilizează limba pe care a deprins-o pentru a-și manifesta libertatea de expresie în planul relațiilor sintagmatice: „Vorbirea înseamnă întotdeauna a comunica. Or, prin comunicare, ceva se convertește în ceva comun; mai exact spus, comunicarea există pentru că cei care vorbesc au deja ceva în comun, care se manifestă în vorbirea unuia cu celălalt" (Coșeriu, apelînd, la rîndul său, la Dewey şi Heidegger).

Schimbarea lingvistică își are originea în dialog: tot ceea ce se îndepărtează de modelele lingvistice existente reprezintă o inovație ${ }^{23}$, iar, în măsura în care această inovație trece de granița manifestării individuale,

\footnotetext{
${ }^{22}$ Nicolai Hartmann, în Das Problem des geistigen Seins [Problema ființei spirituale] (p. 219), își afirma (ca parte a sistemului său filosofic privind independența realității față de capacitatea înțelegerii) concepția ontologică despre limbă: „Viața limbii nu este diferită de viața vorbitorilor, nu este situată, la modul general, alături de ea sau deasupra ei."

${ }^{23} \mathrm{Cu}$ posibilele variante: alterare a unui model tradițional, selecție între modelele posibile de realizare lingvistică anterioare și care nu depășiseră calitatea de potență latentă sau existență ipotetică, împrumut, neglijarea distincțiilor superflue în utilizarea concretă a limbii ca fapt de economie funcțională etc.
} 
devine un fapt social, deci o inovație lingvistică ce a fost adoptată ${ }^{24}$ în comunitatea respectivă, astfel încît ea încetează a mai fi o inovație prin faptul că nu mai este percepută ca atare în masa utilizatorilor unui anume sistem lingvistic ${ }^{25}$. Ceea ce la început apare ca fiind o inovație cu caracter individual, prin adoptare (adică prin transformarea acelei inovații în tradiție), devine expresia unei exigențe interindividuale manifestată în cadrul dialogului ${ }^{26}$. Schimbarea lingvistică este esențială pentru existența în sine a limbilor, pentru că o limbă care nu se schimbă are permanență, deci se fixează definitiv în forma ei, devenind doar sistem și încetînd a mai fi proces ${ }^{27}$. Ar rezulta de aici o limbă abstractă, cum am arătat anterior, mai mult chiar decît un simplu decupaj fixat în sincronie, care este totuşi un decupaj real, la un anume moment dat, din utilizarea concretă a unei limbi. Limba se adaptează la necesitățile de exprimare a vorbitorilor și continuă să existe ca limbă reală doar în situația în care procesul de adaptare este unul neîntrerupt, chiar și în situaţia, des întîlnită, în care adaptarea înseamnă reluarea unor modele anterioare, în măsura în care aceasta este cerută de libertatea lingvistică și de finalitatea ultimă a utilizării limbii: comunicarea.

Se impune în acest punct al discuției o clarificare. Sensurile pe care le capătă în acest context noțiunea de dinamică se diversifică și, mai exact, devin de o complexitate ce necesită o atenție aparte. Am văzut deja că dinamica limbii presupune schimbarea, o modificare rezultantă a procesului de inovare și, ulterior, de adoptare succesivă prin care se realizează tranziția de la cultura lingvistică individuală a vorbitorului la cultura lingvistică a grupului utilizator al aceluiași sistem lingvistic. Aceste schimbări se pot produce însă cu urmări diferite la nivelul echilibrului sistemului sau, altfel spus, pot avea consecințe diferite în economia limbii: unele se pot sedimenta, astfel încît forme vechi sînt înlocuite de forme noi; altele există doar pentru ca limba, prin mecanismele ei, în uzul concret, real, adică în vorbire, să decidă inutilitatea respectivei schimbări și să revină asupra schimbării, revenind în același timp la forma anterioară sau, posibil, adoptînd o altă formă, nouă la rîndul său (ori din punct de vedere material, ori ideal); altele pot exista în decupaje cognoscibile și recognoscibile din timp sau spațiu, fără a afecta în ansamblul ei limba, deci schimbări neutre din punctul acesteia de vedere ${ }^{28}$. Modificările (schimbările) pot așadar fi sau neutre, sau aducătoare de regres, sau aducătoare de progres.

În acest sens în Wald (2017) se arată că: „,[n]u tot ce e nou e progresiv, teza post hoc ergo melius hoc nu-și găsește întotdeauna aplicarea. Aceasta, pentru că se produc și modificări care nu afectează calitatea sau care complică inutil sistemul”; și mai departe: „noțiunea de «progres» nu poate fi substituită prin aceea de evoluție. În cadrul evoluției unui fenomen, se produc modificări în direcția progresului sau a regresului său, ori care nu-i modifică în nici un fel calitatea. Progresul reprezintă numai o latură a evoluției, și anume aceea care exprimă trecerea de la o calitate la o calitate superioară. Și în ceea ce privește limba este evident că nu putem interpreta orice modifi-

\footnotetext{
${ }^{24}$ Schimbarea în limbă reprezintă generalizarea unei inovații (fapt de vorbire, deci de utilizare individuală a limbii în context social ca parte a procesului de comunicare), printr-o serie de adoptări succesive (transformarea unei experiențe în fapt de limbă, deci devenind la rîndul său punct de plecare pentru alte inovări în procesul de refacere continuă a limbii).

${ }^{25}$ Atît vorbitori, cît și ascultători, mai ales avînd în vedere faptul că sistemul lingvistic este un sistem de posibilități cunoscute, acceptate și utilizate (cu o frecvență suficientă) în întreaga comunitate lingvistică.

${ }^{26}$ Din acest punct de vedere, limba reprezintă o creație colectivă, nu în sensul în care toți vorbitorii contribuie cu aceeași inovație în același timp, ci că fiecare vorbitor inovează la un anume moment dat și că aceste inovații sînt succesiv (sau simultan) adoptate de către ceilalți vorbitori ce aparțin aceleiași comunități lingvistice.

${ }^{27}$ Afirmam anterior că în planul paradigmatic, semnele sînt investite cu o valoare virtuală în orientarea procesului de semnificare, în funcție de clasele și categoriile de semne în care se află grupate, iar în planul sintagmatic, varietatea virtuală este înlocuită de o alegere concretă.

${ }^{28}$ Deși este greu de acceptat faptul că unele forme pot apărea, exista sau pot să își înceteze existența fără a afecta în vreun fel limba, ca și cînd nu ar fi existat. Neutralitatea schimbărilor are cel mult un caracter teoretic, căci în fapt linearitatea înseamnă, pentru limbă, degenerare: „Structurile sintactice și mai cu seamă termenii devin tipare în care se toarnă formule eufemistice, metafore convenționalizate, clișee, în strădania de a crea și impune un registru orientat conform unei ideologii, apoi de a-1 extinde dincolo de domeniul apariției sale. Întrucît limba nu mai ascultă de gîndire—spre a reda rațiunea acesteia—, astfel de structuri nu pot oferi o perspectivă cognitiv lingvistică, dar forțează un construct ideologic a cărui mișcare poate fi, cel mult, lineară (adică degeneratoare, nu evolutivă - nota autorilor), prin care limba înlocuiește realitatea și gîndirea” (Gafton \& Gafton,
} 
care ca semn al progresului sau al regresului ei. După cum nu putem considera nici că limbile își păstrează, în cursul istorici, calitatea, modificîndu-se doar în amănunte neesențiale”.

$\mathrm{Cu}$ referire la aceste schimbări, nu se justifică semnul de egalitate semantică pus deseori între dinamică, schimbare, progres, evoluție. Dintre acestea, doar primele două (dinamica și schimbarea) formează o pereche în sens, referindu-se la permanenta mobilitate a sistemelor lingvistice în accepțiunea dată anterior: limba se adaptează la necesitățile de exprimare a vorbitorilor și continuă să existe ca limbă reală doar în situația în care procesul de adaptare este unul neîntrerupt, chiar și în situația, des întîlnită, în care adaptarea înseamnă reluarea unor modele anterioare, în măsura în care aceasta este cerută de libertatea lingvistică și permisă de cultura lingvistică și de contextul socio-istoric; tot ceea ce se îndepărtează de modelele lingvistice existente reprezintă o inovație, iar, în măsura în care această inovație trece de granița manifestării individuale, devine un fapt social, deci o inovație lingvistică ce a fost adoptată în comunitatea respectivă, astfel încît ea încetează a mai fi o inovație prin faptul că nu mai este percepută ca atare în masa utilizatorilor unui anume sistem lingvistic ${ }^{29}$. Dinamica înseamnă o schimbare ce asigură progresul sau regresul limbii, ambele aspecte, alături de modificările neutre, reprezentînd în fapt evoluția limbii, ce depinde de trei factori: (a)creșterea numărului de unități in fiecare nivel al limbii, (b)transformarea calitativă a conținutului lor și (c)întărirea caracterului sistematic al fiecărui nivel și al limbii.

Din punct de vedere fonetic (constituirea inventarului fonologic al limbii şi organizarea fonemelor în sistem și a dinamicii interne a acestuia), o evoluție ascendentă, în formă de spirală, se recunoaște în istoria complexului sonor al cuvintelor, în raport cu conținutul lor semantic, fiind parcurse trei etape: (1) a predominării aspectului motivat al formei sonore, (2) a predominării, dimpotrivă, a aspectului nemotivat, (3) a unei motivări relative, abstracte și sistematice, în care motivarea nu se manifestă față de realitatea extralingvistică, ci față de sistem. Limba dobîndește, aşadar, o stare superioară, definită prin capacitatea de creare a unor cuvinte care, păstrînd capacitatea de a reda un conținut abstract, prezintă și avantajul că pot fi ușor înțelese și memorate, pot fi refăcute de fiecare vorbitor.

În domeniul lexicului, criteriul sporului cantitativ (rezultat al acțiunii duble de achiziție a unor termeni și de pierdere a altora - pe fondul prefacerilor sociale și culturale) este cel mai slab în stabilirea gradului de progres al limbii. El capătă greutate numai asociat cu cel al calităţii cuvintelor, al forței lor semantice. Din acest punct de vedere, limba cunoaște trei poziții, dispuse tot sub formă de spirală, în ascensiune $^{30}:$ (1) etapa generalului nediferențiat și vag, (2) etapa notării precise și a concretului, (3) etapa abstractului logic.

Cea mai complexă problematică este ridicată de morfologia limbii, aceasta impunînd examinarea diacronică a mai multor microsisteme în relație cu lexicul și cu sintaxa. Dar ea oferă și cel mai slab temei pentru a vorbi despre evoluție, cu atît mai puțin despre progres în limbă. Dificultatea demersului este sporită de faptul că, în sine, morfologia reprezintă compartimentul lingvistic care deosebește cel mai mult limbile una de cealaltă, împiedicînd ajungerea la concluzii unitare și uniformizatoare. Limbi contemporane înrudite, care au aceleaşi trăsături structurale și care sînt considerate a se afla pe aceeași treaptă de dezvoltare, pot etala particularităţi morfologice mult distanțate, chiar contrare. Cu toate că, în ansamblu, se poate admite funcționarea acelorași legi sau principii generale de schimbare gramaticală, independente de vreo cauzalitate specifică unei limbi anume (optimizarea, de exemplu, este un principiu universal și comun tuturor epocilor), ritmul în care operează acestea este distinct și, în consecință, diferențiator. Direcția ascendentă a evoluției limbii este dată de tendința de abstractizare a conținutului categoriilor morfologice şi de sistematizare a lor.

Tendințele de evoluție în sintaxă, ca și în vocabular, se dovedesc mai ușor de observat. Aflată în legătură directă cu formele gîndirii, sintaxa oglindește gradul de abstractizare și complexitate ale acesteia; prin

\section{6).}

${ }^{29}$ Toate acestea în ciuda unor perspective care așezau și schimbarea și progresul într-o pereche semantică: Karl Vossler, de exemplu, consideră că orice inovație, adoptată ulterior de comunitatea de vorbitori, reprezintă în mod automat un progres.

30 „[s]-ar putea spune că, prin cantitatea de cuvinte abstracte pe care o conține, fondul principal reflectă, în mai mare măsură 
urmare, dacă se admite existența unui progres în privința gîndirii, se admite, pe cale de consecință, și un progres al sintaxei: „Creșterea numărului de raporturi, a frecvenței și a varietății lor impune limbii o mai strictă organizare, care se traduce prin recțiune în propoziție și hipotaxă în frază. De la forme sintactice simple (topică, intonație), la forme morfologice abstracte, cum sînt cele ale flexiunii și ale acordului care rezultă de aici, și apoi la forme sintactice specializate (prepoziții, conjuncții), sintaxa înregistrează continuu evoluția gîndirii de la concret la abstract și, de aici, la concretul logic, fază superioară abstractului, cuprinzînd în sine atît abstractul, cît și specificarea" (Wald, 2017).

\section{Evoluţia în limbă}

În concluzie, nu voi opta aici pentru noțiunea de progres. Din cele prezentate anterior rezultă cu claritate că progresul reprezintă doar o latură a evoluției și că este extrem de dificil a surprinde numai trecerea de la o calitate la o calitate superioară ${ }^{31}$. Limba se schimbă în orice sens, limba se caracterizează prin dinamică și, pentru aceasta, evoluează. Voi reține astfel termenul de dinamică, dublat de cel de schimbare, în strînsă legătură cu cel de evoluție, caracteristică de altfel a realității a cărei parte este limba și pe care aceasta încearcă să o dezvăluie ${ }^{32}$. Realitatea, în dimensiunile ei evolutive, este sistemică, așa cum am surprins anterior, cu funcțiuni ce decurg din propria constituție, în relație cu solicitările mediului și respectînd principii universale. Limba este o creație naturală, nu o construcție logică și rațională, supunîndu-se acelorași principii universale, iar cauzele schimbării acesteia, atît cele de ordin lingvistic ${ }^{33}$, cît și cele de ordin extralingvistic ${ }^{34}$, reflectă cu fidelitate direcția forțelor care induc tendințele de echilibrare și din a căror acțiune decurge procesul.

În Laland (2014) se operează o distincție clară, deși dificil de realizat în practică, între cauze și proces. Astfel, există cauze ale evoluției, adică evenimente care generează contextul propice evoluției, și un proces de evoluţie $e^{35}$, adică o dinamică ce determină progresul sau regresul sau reluarea fără modificări într-o formă de existență nouă a unei forme de existență precedente.

Atunci cînd un vulcan erupe, se produc fenomene extreme ce își pun radical amprenta asupra mediului înconjurător. Magma și gazele fierbinți se scurg pe versantul muntelui, curentul de lavă distrugînd fiecare ființă vie pe care o întîlnește. Erupțiile de o asemenea amploare sînt printre cele mai distructive dezastre naturale pe care știința le cunoaște. Totuşi, chiar și într-un asemenea context se observă dovada adaptării evolutive. De exemplu, un vulcan subacvatic din Guam a erupt în 2004 iar cercetările vieții marine din zonă au descoperit ulterior varietăți neobișnuite de pești, creveți, crabi și melci, inclusiv cîteva specii noi. Aceste organisme trăiesc fără probleme în apa fierbinte, contaminată chimic, datorită faptului că prezintă o modificare anatomică care le permite să supraviețuiască la concentrații foarte ridicate de sulfuri. Aparent, modificările aduse mediului de erupția vulcanică au cauzat schimbări evolutive prin selecția naturală a organismelor capabile să tolereze sau să exploateze în folos propriu condițiile ecologice severe create. În gîndirea comună ar fi pe deplin justificabil să se vorbească despre vulcan ca o cauză a evoluției;

decît vocabularul în ansamblu, nivelul de dezvoltare a unei comunități, cîtă vreme el indică nu cîte cuvinte abstracte are o limbă, ci ce fel de noțiuni abstracte au devenit curente pentru vorbitori” (Wald (2017))

${ }^{31}$ Degradarea limbii este un fenomen nu mai puțin natural decît progresul în existența limbilor. De regulă, degradarea sau regresul reprezintă o fază de dezechilibru în evoluție, căreia limba însăși îi opune tendința de progres, de sistematizare, bunăoară, și, prin urmare, asupra căreia revine reparator, mai devreme sau mai tîrziu. Mult mai rar, procesul de degradare se încheie cu dispariția limbii. Cauzele sînt diverse: accidente de natură diversă, condiții istorice nefavorabile, presiunea altor coduri lingvistice, reducerea valorii sociale a limbii respective, stingerea populației vorbitoare etc. (Chirilă \& Gafton, 2017).

${ }^{32}$ Limba nu poate fi altfel decît realitatea, secvența nu poate fi diferită de întregul din care aceasta face parte, la fel cum celula nu poate funcționa după reguli altfel decît cele care guvernează organismul în a cărui componență intră.

${ }^{33}$ Acțiunea eroziva a legilor fonetice, dinamica sistemului, a componentelor și a elementelor sale.

${ }^{34}$ Schimbările de la nivelul civilizației, culturii, mentalității, nevoile și descoperirile epocilor.

${ }^{35}$ Se face aici corecta și necesara distincție între evoluția generalizată și evoluția de nișă, aceasta din urmă însemnînd moduri particulare de evoluție, similare cîtă vreme se manifestă în contexte asemănătoare pînă la identitate. 
totuşi, nici vulcanii, nici alte schimbări ale mediului nu sînt definite în textele de specialitate drept cauze ale schimbării evolutive.

Aceasta nu înseamnă că adepții evoluționismului nu apreciază legătura cauzală între schimbările de mediu și schimbările organismelor: bineînțeles că o apreciază. Această relație a fost foarte bine stabilită încă de către Darwin, în Originea speciilor. Totuși, evoluționiștii vor face în mod tipic o distincție între acele procese care aduc schimbări în funcție de condițiile de mediu înconjurător (printre care și erupțiile vulcanice) și acele procese care aduc schimbări ereditare de durată în organisme prin modificarea frecvenței genelor (unde vulcanii nu sînt incluși). Pentru adepții evoluționismului, cauza reală a acestei adaptări a organismelor pentru a tolera temperaturile extreme și concentrațiile de substanțe chimice este selecția naturală. Sînt recunoscute și alte cauze directe ale evoluției, precum, de exemplu, anomaliile genetice întîmplătoare, moștenirea genetică sau mutațiile genetice. Dar erupțiile vulcanice, ca oricare alt fenomen care modifică mediul în care organismele trăiesc, nu sînt percepute drept cauze directe ale evoluției: mai degrabă ele sînt privite drept circumstanțe.

Această distincție între un fenomen care cauzează apariția unui proces evolutiv și o cauză directă a evoluției ori chiar un proces evolutiv în sine este subtilă, dar importantă. Erupțiile vulcanice nu cauzează organismelor schimbări directe (dacă selecțiile au fost împiedicate, de exemplu, prin absența variației ereditare, nu ar apărea nici o schimbare a organismului): mai degrabă, ele creează condițiile sub care selecția naturală poate (sau nu poate) apărea. A se nota că aceasta este o descriere diferită a cauzalității față de cea găsită în limbajul comun sau chiar în alte științe. Dacă un cui este lovit cu ciocanul, ciocanul va fi perceput ca o cauză directă a intrării cuiului într-o scîndură. Ar părea straniu să se afirme că forța de impact a ciocanului reprezintă doar o circumstanță a intrării cuiului în scindură. După știința mea, fizicienii nu văd nevoia de a separa logic procesul de mișcare a ciocanului de procesul de pătrundere a cuiului în scîndură. La fel, nu aș fi optimist cu privire la șansele unui inculpat de a nu fi condamnat dacă apărarea sa ar fi bazată pe argumentul că nu el, ci glonțul, a provocat moartea victimei pe care a împușcat-o (Laland, 2014).

În același sens al discuției, Laland identifică și existența unor cauze reciproce ${ }^{36}:$ mediul furnizează cauzele evoluției ce declanșează procesul evoluției. Apoi, individualul deja modificat schimbă la rîndul său contextul, căci generalul este suma individualităților care îl compun, context care, din nevoia de echilibru, devine astfel, din nou, cauză a evoluției. Există două etape ale manifestării acestui proces, succesive și alternante: (1) dinspre context înspre individual: conformismul ${ }^{37}$ este cel care funcționează, căci individualul tinde să urmeze punctul de vedere al majorităţii, cu atît mai mult cu cît această majoritate se bucură și de atributul autorității; (2) dinspre individual înspre context: se manifestă aici un conflict moderat ${ }^{38}$, se dezvoltă o strategie stabilă de evoluție ce evită salturile majore, imposibil de realizat la nivelul unui context caracterizat prin stabilitate. Evoluția se realizează cu paşi mărunți, ceea ce este mai puternic se manifestă în sensul dominării a ceea ce este mai slab, astfel încît ajunge, în final, să devină în sine o realitate contextuală ce va influența la rîndul său individualul, respectînd principiul conformismului.

În perspectivă darwinistă ${ }^{39}$, selecția produce evoluție, percepută ca o schimbare continuă, iar prin competiție, forma nouă va elimina propriile sale forme parentale mai puțin perfecte și alte forme mai puțin favorizate.

\footnotetext{
${ }^{36}$ Se manifestă în această situație reciprocitatea, consecuția, socialitatea, istoricitatea.

${ }^{37}$ Relația individual - conformism - social este teoretic și experimental tratată în Fessler et al. (2015).

${ }^{38}$ Ideea conflictului moderat în cadrul aceleiași specii și manifestarea sa ca strategie stabilă de evoluție este tratată în Maynard-Smith \& Price (1973).

${ }^{39}$ Pentru stadiul în care se află, azi, darwinismul, o pledoarie pentru științele naturii, pentru corecta înțelegere a lumii, se regăsește la Kellogg (2017). Aceleași specii rămîn adesea constante în condiții externe foarte diferite, atît de natură organică cît și de natură anorganică. Spune Darwin: „Pentru cel care privește clima și condiţiile fizice ale vieții ca fiind cele mai importante elemente ale distribuției, aceste fapte trebuie să fie surprinzătoare, căci clima și înălțimea sau adîncimea se diferențiază
} 


\section{Concluzii}

Limba este un organism viu, supus evoluției universale, prin variație și selecție ${ }^{40}$. Ca materie sonoră pe care gîndirea o transformă pe nesimțite și fără finalitate, sub acțiunea inconștientă a luptei pentru existență și a selecției naturale, organismul viu—limba—se află într-o perpetuă evoluție, dată de echilibrul relativ și de concurența dintre o forță conservatoare și una revoluționară. Acest aspect grevează epocile în mod progresiv, proporțional cu amplitudinea spaţiului de comunicare și cu viteza de circulație a acesteia. Deși echilibrul dintre stabilitate și variabilitate este unul natural, cum am arătat anterior, el tinde să torsioneze organismul peste limitele suportabile, forțele conservatoare tinzînd către păstrarea statu quo-ului, cele „revoluționare” tinzînd să impună schimbarea ca pe o realitate perpetuă, într-o dinamică nestăvilită, care nu mai dă loc fireștilor sedimentări. Întrucît variabilitatea naturală este în mod firesc destul de mare, cei care ar trebui să domine sînt factorii stabilizatori, acțiunea lor continuă fiind necesară și asigurînd evoluția naturală a sistemului.

În plus, orice tendință de a restabili un echilibru afectat de variabilitate nu duce la revenirea la echilibrul anterior, ci la refacerea acestuia pe o altă treaptă evolutivă. Simpla acțiune a individului generează variabilitate, această presiune fiind gestionată de forțele stabilizatoare. În condițiile, însă, ale presiunilor venite dinspre mediu, dinspre comunitățile tot mai mari de indivizi (ca urmare a acțiunii puternice a civilizației asupra lor), factorii prin care se produce stabilizarea ${ }^{41}$ slăbesc tot mai mult, nemaiavînd forța de a aduce și păstra vremelnic echilibrul. În acest caz, dimpotrivă, forța „revoluţionară” începe să acționeze singură și continuu, singurul lucru și fapt care conferă și asigură existență reală oricărei entități (echilibrul stabil) dispărînd, cu consecințe asupra identităţii organismului.

Rezultat al tensiunii evolutive, jocul dintre stabilitate și variabilitate, dintre prezervare și inovație, reflectă nevoile interne ale organismului în raport cu sine și cu mediul, precum şi pe cele externe ale sale, în raport cu contextul în care există și funcționează, fiind unul adaptativ. Atît pentru organism, cît și pentru structura complexă din care acesta face parte, acest joc trebuie să fie unul rezonabil, înclinînd uşor în favoarea celei dintîi forțe, viața și sănătatea limbii decurgînd din urmarea cît mai reticentă a forței inovatoare. Cea din urmă este precum oxigenul, asigurînd combustia necesară întreținerii existenței și devenirii, cea dintîi este precum carbonul, asigurînd dăinuirea ca atare a țesăturii organice ce constituie orice ființare. Tendința lor firească este egoistă, însă doar pentru a crea tensiunea necesară existenței în evoluție, ambele fiind necesare și complementare, nici una netrebuind exclusă, nici una netrebuind să prevaleze. În acest context, este dificil de arătat dacă soluția existenței echilibrate stă în implicarea rațiunii sau în urmarea naturii.

Între limbă și gîndire există o strînsă relație de interdeterminare, limbile reflectînd habitudinile mentalitare, spirituale și psihologice ale popoarelor. Faptul că, uneori, formele vechi se încarcă cu sensuri noi indică influența călăuzitoare și modelatoare pe care spiritul o are asupra limbii, dar și caracterul rezilient al formei, greu abandonabile. Așa cum biologia este istoria diferențierii prin adaptare la medii diferite, tot astfel limba se supune transformismului, pe care îl consideră a fi legea evoluției limbajului. Desigur, diferențele dintre limbi reflectă diferențe de gîndire cu profunde implicații generatoare de deosebiri critice

imperceptibil. Dar dacă ținem seama că aproape fiecare specie, chiar în centrul arealului ei, ar crește teribil în număr dacă nu ar fi celelalte specii competitoare, că aproape toate speciile fie prădează, fie servesc drept pradă - pe scurt, dacă ne gîndim că fiecare organism este direct sau indirect legat în cel mai intim mod de celelalte organisme, observăm că răspîndirea locuitorilor oricărui ținut nu depinde în nici un caz exclusiv de condiții fizice subtil schimbătoare, ci depinde în mare parte de prezența altor specii, pe seama cărora trăiesc sau îi distrug, sau cu care intră în competiție; și, din moment ce aceste specii deja constituie obiecte definite, care nu trec unele în altele prin gradații fine, răspîndirea oricărei specii, depinzînd de răspîndirea celorlalte, va tinde să fie clar delimitată.” Selecția urmează variația, nu variația urmează selecția.

${ }^{40}$ A se vedea, pentru această abordare, Darmesteter (2015). Cele prezentate în continuare reprezintă punctul de vedere exprimat în Nota traducătorului.

${ }^{41}$ Naturali: acțiunea civilizației, respectul pentru tradiție, supravegherea limbajului copiilor, tendința către un limbaj ales și standardizare, bunul simț înnăscut. Culturali: urmarea modelelor constituite de textele sacre și de cele literare, cultivarea gîndirii și a oamenilor de calitate. 
de ordin cultural-spiritual și mentalitar.

\section{Bibliografie}

Benveniste, E. (1966). Problemes de linguistique generale, Gallimard, Paris.

Chirilă, A. \& Gafton, F. (2017). Recenzie la Lucia Wald, Progresul în limbă. Scurtă istorie a limbajului. Ediția a II-a, revăzută. Text îngrijit, notă asupra ediției și prefață de Petre Gheorghe Bârlea, Editura Universității „Alexandru Ioan Cuza”, Iași, 2017, 346 p., în „Diacronia”, nr. 6, 30 sept., A94, Crossref.

Coșeriu, E. (1997). Sincronie, diacronie și istorie (trad. N. Saramandu), Editura Enciclopedică, București.

Darmesteter, A. (2015). Viaţa cuvintelor studiată în semnificațiile lor (trad. Al. Gafton) Editura Universității „Alexandru Ioan Cuza”, Iași.

Dessalles, J.-L. (2017). Către originile limbajului. O istorie naturală a vorbirii (trad. Al. Gafton), Editura Universității „Alexandru Ioan Cuza”, Iași.

Irimia, D. (1978). Curs de lingvistică generală, manual universitar de uz intern.

Irimia, D. (2011). Curs de lingvistică generală (ed. I. Milică \& I. Moisuc), ediția a III-a, Editura Universităţii „Alexandru Ioan Cuza", Iași.

Fessler, D.M.T., Barrett, H.C., Kanovsky, M., Stich, S., Holbrook, C., Henrich, J., Bolyanatz, A.H., Gervais, M.M., Gurven, M., Kushnick, G., Pisor, A.C., von Rueden, C. \& Laurence, S. (2015). Moral parochialism and contextual contingency across seven societies, în „Proceedings. Biological Sciences”, vol. 282, 20150907, Crossref.

Gafton, Al. \& Gafton, E. (2016). Reality, Science, Method, în „GIDNI”, IV, p. 9-24.

Graur, Al., Stati, S. \& Wald, L. (1971). Tratat de lingvistică generală, Editura Academiei R.S.R., București.

Kellogg, V.L. (2017). Darwinismul astăzi (trad. Al. Gafton, A. Chirilă), Casa Editorială Demiurg, Iași.

Laland, K.N. (2014). On evolutionary causes and evolutionary processes, în „Behavioural Processes”, vol. 117, p. 97-104, Crossref. Maynard-Smith, J. \& Price, G. R. (1973). The logic of animal conflict, in „Nature”, vol. 246, p. 15-18, Crossref.

Saussure, F. de (1998). Curs de lingvistică genarală (trad. I. Izverna Tarabac), Editura Polirom, Iași.

Wald, L. (2017). Progresul inn limbă. Scurtă istorie a limbajului, ed. a II-a revăzută, Editura Universității „Alexandru Ioan Cuza”, Iaşi. 